Article

\title{
Does Housing Policy Sustainability Matter? Evidence from China
}

\author{
Ya Gao ${ }^{1}$, Xiuting $\mathrm{Li}^{1,2}$ and Jichang Dong ${ }^{1,2, *}$ \\ 1 School of Economics and Management, University of Chinese Academy of Sciences, Beijing 100190, China \\ 2 Key Laboratory of Big Data Mining and Knowledge Management, Chinese Academy of Sciences, \\ Beijing 100190, China \\ * Correspondence: jcdonglc@ucas.ac.cn; Tel.: +86-10-8268-0675
}

Received: 7 August 2019; Accepted: 28 August 2019; Published: 31 August 2019

check for updates

\begin{abstract}
The housing market plays an important role in the Chinese economy and society. To promote the functioning of the housing market, the Chinese government has imposed many policies and regulations. However, most of these regulations do not take sustainability into consideration. Using a difference-in-difference approach, this paper investigated the impacts of home purchase restriction (HPR) on the housing market in China. While most studies have only focused on the impacts of HPR implementation on the housing market, we also investigated the effects of HPR removal. The results revealed that HPR brings about a decline in the growth of house prices and the impacts are more significant in the short run. Furthermore, the effects of HPR vary across different cities., where they are particularly pronounced in the central and western cities. Moreover, there was no evidence to show that the removal of HPR affected house prices as expected. This suggests that it is important to improve the sustainability of housing policies, which has significant policy implications for obtaining a well-functioning housing market.
\end{abstract}

Keywords: home purchase restriction; house price; difference-in-difference; regional housing market; policy sustainability

\section{Introduction}

House prices have grown rapidly in China in recent years [1], which has had profound impacts on society and the economy [2-8]. Moreover, surging house prices have recently become a major concern as it negatively affects social sustainability. On one hand, it has been observed that the growth rate of house prices has exceeded household income growth [9], thereby influencing the household housing affordability [10-12], housing inequality, and even social sustainability in China [13]. On the other hand, the surging house prices in China may increase the risk of bubbles bursting and damaging the sustainability of urban development [14]. To promote the sustainable growth of the housing market and economy, the Chinese government has introduced a series of policies and regulations. However, due to the lack of a long-term mechanism for the regulation of the housing market, almost none of these policies and regulations have been implemented continuously, which has contributed to inconsistencies in regulating the housing market. In order to build up a long-term regulation mechanism and improve the functioning of the housing market, it is important to understand the effects of policy sustainability in the housing market.

Among all the regulations in the housing market, home purchase restriction (HPR) has drawn great attention. By restricting mortgages, limiting household' access to home purchases as well as the amount of home purchasing, HPR has imposed strict limits on the demand side of the housing market. Nevertheless, most cities have not implemented HPR continuously. In this paper, we use HPR as an example of housing policy and study the impacts of HPR dynamics on the housing market. 
Our objectives are two-fold. The first is to investigate the impacts of HPR on the housing market. In particular, this research focused on the impacts of HPR dynamics and also explored the heterogeneity in the effect of HPR. For instance, we examined the short- and long-run effects as well as the regional effects of HPR. Based on the analysis of HPR, our second objective was to study the effects of sustainability policy in the housing market.

We contribute to the HPR literature in the following ways. First, as the existing literature shows mixed evidence of the impacts of HPR, we tried to study the effects of HPR from a more comprehensive perspective. Second, previous studies have not dealt with the impacts of the removal of HPR. In this paper, we track the dynamics of HPR by investigating the impacts of the implementation and removal of HPR. This has important policy implications and practical significance because the understanding the effects of sustainability policy is essential in establishing a long-term regulation mechanism and promoting the functioning of the housing market. Third, in terms of the methodology, most studies employ a difference-in-difference (DID) approach in which to study the impacts of HPR. However, they may violate the common trend assumption and lead to an inconsistent estimator. In this research, we employed a DID approach to investigate the effects of HPR on house prices. Furthermore, to address the potential problem of DID analysis, we also introduced a difference-in-difference-in-difference (DIDID) and a propensity score matching-difference.

The remainder of this paper is organized as follows. Section 2 briefly reviews the relevant literature. In Section 3, we introduce our empirical strategy and our data. Section 4 reports the main empirical results of our analysis. The robustness test is presented in Sections 5 and 6 concludes.

\section{Literature Review}

Since the market-oriented reform in China in the 1980s, the real estate industry has experienced rapid development. With the rapid development of the housing market, the government has played a crucial role. According to Cao and Keivani [10], the development of the Chinese housing market can be summarized in four stages. First, from 1998 to 2004, the housing market grew rapidly after the market-oriented reform. Second, from 2005 to 2008, to cool down the surging house prices, the central government implemented a series of interventions on the housing market. Meanwhile, the global financial crises since 2007 has had negative impacts on the housing market. Consequently, the housing market experienced a slowdown in this period. Third, from 2008 to 2009, the central government imposed several policies to boost the demand of the housing market. For example, in the Opinions on Promoting the Healthy Development of The Real Estate Market, the State Council promised to ease the credit restrictions. Fourth, since 2010, the central and local government has implemented combined regulations to curb soaring prices in the housing market [1] with the aim to establish a long-term and sustainable regulation mechanism to achieve a sustainable housing market [13].

In fact, the excessive growth of house prices in recent years has become a major concern in China. In order to restrain the surging prices in the housing market, the central and local government have introduced the home purchase restriction (HPR). On April 17, 2010, the State Council issued the notice of "curbing the excessive increase in house prices in some cities". The notice put forward that all regions could limit the number of home buyers according to their local conditions. On April 30, 2010, Beijing took the lead in introducing the detailed rules of HPR, which stipulates that every household can only purchase one additional commercial house. In 2010-2011, many cities released their detailed HPRs. Although HPR seems to be effective in curbing the growth of house prices, the implementation of HPR is not continuous in most cities. As the economy changed, most cities (except for Beijing, Shanghai, Guangzhou, and Shenzhen) loosened and even abandoned HPR from 2014 to 2016. Nevertheless, after the short-term removal of HPR, an increasing number of cities have returned to HPRs since 2017.

Many papers have focused on the effects of HPRs on the housing market, but the conclusions are mixed. By comparing the effects of these detailed HPR policies in 35 major cities, Li and Xu [15] concluded that xiangou (restricting house purchase) was the most effective policy to curb the soaring house prices. Du and Zhang [16] compared the effects of HPR and the property tax in Beijing, Shanghai, 
and Chongqing and found that HPR was more effective in curbing the rising house prices than the property tax, therefore, HPR could not be replaced by the property tax in the short run. In contrast to Du and Zhang, Wang and Huang [17] compared the effects of HPR and property tax and concluded that the influences of HPR were relatively limited. Regarding the reason, Zhou [18] believes that sentiment plays an important role in housing market regulations, and the optimism in the housing market may reduce the effectiveness of HPR.

In fact, empirical evidence also reveals that there is a heterogeneity effect of HPR on the housing market. First, the impacts of HPR may be different in the short-run and long-run. For example, Sun et al. [19] emphasized the short-term impacts of HPR. Based on the resale and rental transaction data from 2005 to 2011 in Beijing city, they concluded that HPR contributed to a decrease in the resale price and transaction amounts. Similarly, Yan and Ouyang [20] used daily house sales data and house prices data from January 2017 to May 2017 to study the short-term impacts of HPR on the housing market. They believe that HPR is effective in reducing housing demand and depressing house prices. However, because they only used data from a relatively short time, there was no evidence to show the long-run effects of HPR. In contrast, Li et al. [21] used the method of mobility probability plot to study the impacts of HPR on house prices and argued that the effect of HPR still existed in the long-run.

Second, the impacts of HPR may differ across regions. Wu and Li [22] used a difference-in-difference approach to analyze the impacts of HPR on the housing market and showed that HPR had impacts on reducing house prices and transaction demands. Furthermore, HPR is more effective in first- and second-tier cities. This idea is also supported by Jia et al. [23], who argued that the effects of HPR may vary across cities. Based on the resale housing transaction data in Guangzhou city, they found that the localized HPR had positive impacts on house prices, but that the central government's HPR led to a drop in house prices.

Unfortunately, the existing evidence of the impacts of HPR is mixed, and a more comprehensive perspective for studying the impacts of HPR on the housing market is lacking. Additionally, most studies have only focused on the impacts of HPR implementation. There is scarce evidence of the effects of HPR dynamics, especially of the effects of HPR removal on the housing market. This is important because the existing literature shows that policy uncertainty and dynamics are associated with house prices [24]. In other words, the dynamics and uncertainty of HPR policy may affect the housing market. Therefore, it is crucial to understand whether sustainability in regulations is effective in the housing market. Moreover, most of the existing studies of the effects of HPR have employed the DID approach, but they may violate the common trend assumption and lead to an inconsistent estimator. To address this concern, we used a DID, DIDID, and a propensity score matching-difference in our analysis.

\section{Data and Methodology}

\subsection{Data}

In this research, we drew data from the National Bureau of Statistics of the People's Republic of China and the city-level bureau of statistics from the first quarter of 2006 to the second quarter of 2016. We restricted our sample to 70 major cities in China, accounting for $10.4 \%$ of the total number of Chinese cities. (By the end of 2018, the total number of Chinese cities reached 672 including 297 cities above the prefecture-level and 375 county-level cities.) We excluded Dali in our sample due to many missing values in the main variables. Therefore, our final sample consisted of 69 large and medium-sized cities in China.

In our analysis, we attempted to study the impacts of the implementation and removal of HPR on the housing market. First, to investigate the impacts of HPR on house prices, we focused on the data between the first quarter of 2009 and the fourth quarter of 2013, covering two years before and three years after the implementation of HPR. According to whether the city introduced HPR between 2009 and 2013, the whole sample was divided into the treatment group and control group. The treatment 
group refers to 39 large and medium-sized cities that introduced HPR between 2009 and 2013, and the control group refers to 30 large and medium-sized cities that did not implement HPR between 2009 and 2013. Second, to study the impacts of HPR removal on the housing market, we used data between the first quarter of 2012 and the second quarter of 2016. According to whether the city had removed HPR since 2014, our sample was divided into the treatment group and control group. The treatment group included 35 large and medium-sized cities that have removed HPR since 2014. The control group consisted of 34 major cities including four cities that have consistently implemented HPR since 2010, and 30 cities that did not introduce HPR between 2010 and 2016. Table A1 in Appendix A shows a city list of the control groups and treatment groups in this paper.

Our main dependent variable was the house price index, which indicates the growth rate of house prices. As HPR may affect the newly-built housing market and second-hand housing market differently, we used both the newly-built and second-hand house price index in our analysis. In addition, considering that many factors may influence house prices, we selected three control variables in our analysis based on the existing literature. The first is the quarterly average land price for residential purposes (LP). Land price affects house prices mainly through the cost mechanism, for example, as a major component of house prices, an increase in land prices drives up the cost, thereby pushing up house prices. In fact, it has been observed that land price is associated with house prices $[14,25]$. The second control variable is the annual gross domestic product (GDP). GDP is widely used as a determinant of house prices $[20,22]$ because it is an indicator of economic development, which interplays with the development of the housing market. The third control variable is the per capita disposable income of urban residents (INC). INC reflects the household income and purchasing power; hence, it is regarded as an important factor in house prices $[13,14,26]$. Detailed variable descriptions are reported in Table 1. Specifically, we used the logarithm of LP, GDP, and INC in our following analysis. Additionally, due to the issue of missing values, we dropped observations in certain specifications and dealt with the missing observations by using different robustness tests.

Table 1. Variable descriptions.

\begin{tabular}{ccc}
\hline Variable & Definition & Unit \\
\hline HP_new & Newly built house price index & $\%$ \\
HP_sec & Second-hand house price index & $\%$ \\
LP(log) & Land prices for residential purposes & RMB per square meter \\
GDP(log) & Annually gross domestic product & RMB \\
INC(log) & Per capita disposable income of urban residents & RMB \\
\hline
\end{tabular}

Table 2 presents descriptive statistics of the key variables between 2009: Q1 and 2010: Q2. We compared the summary statistics before HPR (2009: Q1 to 2010: Q2) and after HPR (2010: Q3 to 2013: Q4). In this table, according to whether the city introduced HPR, we divided the sample into the control group and treatment group. Panel A in Table 2 shows the statistics before HPR, and Panel B presents the values after HPR. As shown in Table 2, the economic development of all cities in our sample developed between 2009 and 2013. However, the control group and treatment groups differed in a number of aspects. On one hand, Table 2 suggests that the treatment group exceeded the control group in both house price levels and economic development. On the other hand, the growth in the newly-built house prices of the treatment group declined from $5.22 \%$ before HPR to $4.17 \%$ after HPR. However, for the control group, the growth of the newly-built house prices increased from $3.24 \%$ to $3.63 \%$, respectively. The difference between the treatment group and the control group may be due to the implementation of HPR. 
Table 2. Summary statistics.

\begin{tabular}{|c|c|c|c|c|c|c|}
\hline \multirow{3}{*}{ Variable } & \multicolumn{6}{|c|}{ A. Pre-HPR (2009: Q1 to 2010: Q2) } \\
\hline & \multicolumn{4}{|c|}{ Control Group } & \multicolumn{2}{|c|}{ Treat Group } \\
\hline & Obs & Mean & Std. Dev. & Obs & Mean & Std. Dev. \\
\hline HP_new & 180 & 3.239 & 4.297 & 234 & 5.221 & 8.993 \\
\hline HP_sec & 180 & 2.178 & 4.181 & 234 & 4.447 & 6.955 \\
\hline $\operatorname{LogLP}$ & 132 & 7.170 & 0.495 & 222 & 8.086 & 0.839 \\
\hline LogGDP & 180 & 4.829 & 0.670 & 234 & 5.608 & 0.906 \\
\hline \multirow[t]{4}{*}{ LogINC } & 180 & 9.678 & 0.186 & 234 & 9.903 & 0.244 \\
\hline & \multicolumn{6}{|c|}{ B. Post-HPR (2010: Q3 to 2013: Q4) } \\
\hline & \multicolumn{3}{|c|}{ Control Group } & \multicolumn{3}{|c|}{ Treat Group } \\
\hline & Obs & Mean & Std. Dev. & Obs & Mean & Std. Dev. \\
\hline HP_new & 420 & 3.627 & 3.606 & 546 & 4.168 & 6.499 \\
\hline HP_sec & 420 & 2.075 & 3.283 & 546 & 2.188 & 5.132 \\
\hline LogLP & 307 & 7.362 & 0.511 & 518 & 8.338 & 0.827 \\
\hline LogGDP & 420 & 5.211 & 0.657 & 546 & 5.982 & 0.876 \\
\hline LogINC & 420 & 9.951 & 0.198 & 546 & 10.181 & 0.258 \\
\hline
\end{tabular}

\subsection{Empirical Model}

We applied a DID approach to study the effects of HPR on house prices. According to whether the city had implemented HPR, we first divided all of the cities into the control group and treatment group. By comparing the differences between the treatment group and the control group across times, we then investigated the impacts of HPR. The dependent variable in the empirical model was the house price index and the basic specification is as follows:

$$
y_{i t}=\beta_{0}+\beta_{1} \text { Post }_{t}+\beta_{2} \text { Treat }_{i}+\beta_{3} \text { Treat }_{i} * \text { Post }_{t}+\gamma Z_{i t}+\varepsilon_{i t}
$$

where $y_{i t}$ is the house price index of city $i$ at time $t$. Treat is a dummy variable that equals 1 if the city belongs to the treatment groups, and 0 if the city is in the control groups. Post equals 0 before the implementation of HPR and it is 1 after HPR. $Z$ is a vector of the control variables, which accounts for the unobservable heterogeneity across cities. Equation (1) is essential to our remainder analysis of the impacts of HPR. The coefficient $\beta_{3}$ is the DID estimator and is the parameter of interest [27]. We expected the coefficients of $\beta_{3}$ to be negative, which shows that the implementation of HPR had negative impacts on house price growth.

The DID approach requires the parallel trend assumption, which means that the dependent variable of the treatment group should have a common trend in comparison to the control group in the absence of HPR. However, it was hard to satisfy this assumption in this paper, because the cities varied significantly in their economic development and housing market development [25]. This may lead to an inconsistent estimator of the DID approach. Therefore, we applied a DIDID analysis to address this concern [28]. By using the regional variations, we introduced a series of binary region indicators and extended the basic specification Equation (1) to Equation (2).

$$
\begin{gathered}
y_{i t j}=\beta_{0}+\beta_{1} \text { Post }_{t}+\beta_{2} \text { Treat }_{i}+\beta_{3} \text { Region }_{j}+\beta_{4} \text { Treat }_{i} * \text { Post }_{t}+\beta_{5} \text { Treat }_{i} * \text { Region }_{j} \\
+\beta_{6} \text { Post }_{t} * \text { Region }_{j}+\beta_{7} \text { Post }_{t} * \text { Treat }_{i} * \text { Region }_{j}+\gamma Z_{i t j}+\varepsilon_{i t j}
\end{gathered}
$$

where $y_{i t j}$ is the house price index of city $i$ in region $j$ at time $t$. Region is a binary indicator. It equals 1 if a city belongs to a specific region and 0 otherwise. In our analysis, we had three region indicators: Region_Eastern took the value of 1 if the city was in the eastern region; Region_Central equaled 1 if the city was located in the central region, and Region_Western was 1 if the city was in the western region. In the DIDID specification, $\beta_{7}$ was our coefficient of interest and captured the differences of 
the net effects of HPR across regions between 2009: Q1 and 2013: Q4. We mainly used OLS methods in our analysis. Additionally, we also employed a least-squares dummy variable (LSDV) since we incorporated a lag-term dependent variable in our model.

\section{Empirical Results}

\subsection{Impacts of Home Purchase Restriction on House Prices}

We first used data from 2009: Q1 to 2013: Q4 to study the impacts of HPR on the housing market. Figure 1 shows the growth rate of commercial house sales from 2009 to 2013. As shown in Figure 1, the growth rate showed a sharp decline in 2010, suggesting that in most cities, the housing demand declined dramatically after HPR. The slowdown in the housing market may further affect house prices. Based on our DID specification, we investigated the effects of HPR on the growth of house prices in the newly-built housing market and the second-hand housing market. The results are reported in Table 3 . In addition, we found that it was important to examine the short-term effects and the long-term effect, respectively, because they may differ in policy effects. On one hand, a time lag of the policy effect may influence the effects of HPR at different time points. On the other hand, the existing evidence suggests that sentiment may influence the effects of government intervention [18]. For the relatively short term, it is hard for households to react to HPR. For the relatively long term, however, households have enough time to react to HPR, thereby influencing the effectiveness of HPR. In this paper, we defined the short-term effects of HPR as the effects of HPR by the end of 2012: Q4. As most cities have removed HPR since 2014, we can only observe the effects of HPR by the end of 2013: Q4. Therefore, we defined the long-term effects as the effects of HPR between 2009: Q1 and 2013: Q4 in this paper.

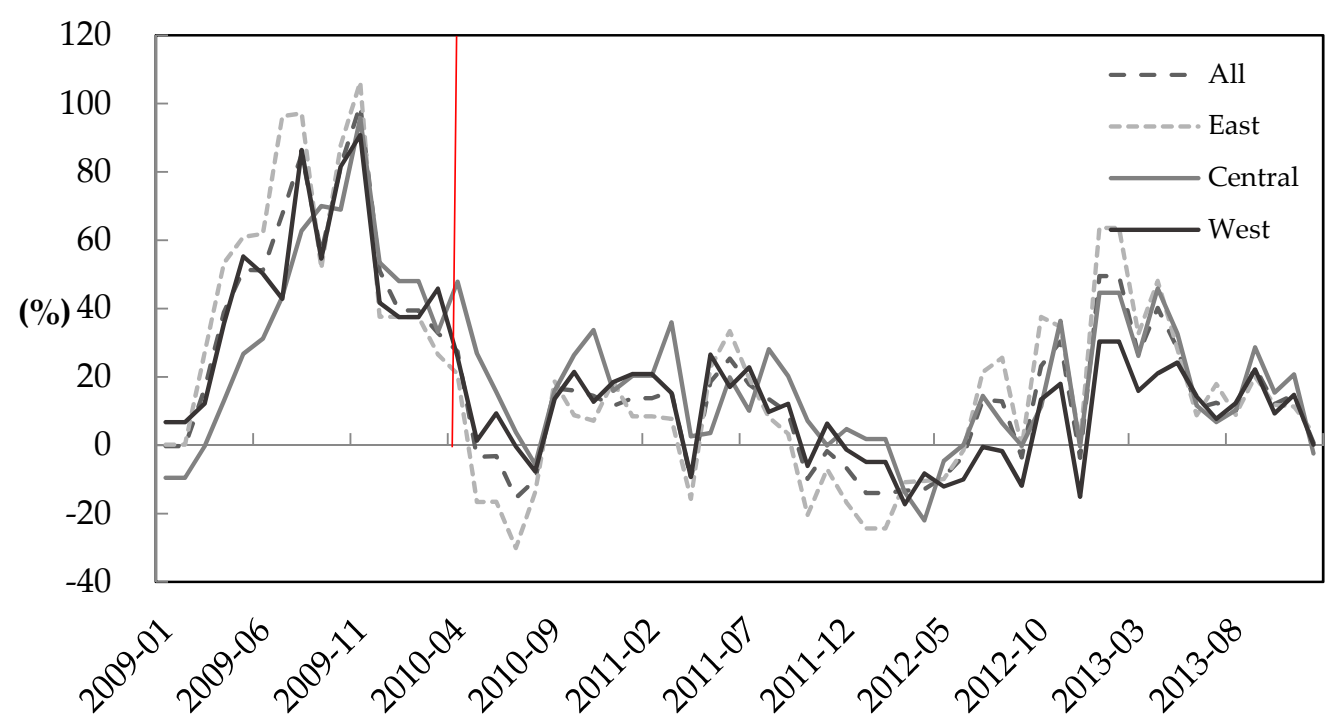

Figure 1. Year-on-year growth rate of commercial house sales from 2009 to 2013. Source: National Bureau of Statistics.

The first four columns of Table 3 report the impacts of HPR on the newly-built house price index. Columns 1-2 report the short-term impacts. In Column 1, we started with a simple specification that only considered the impacts of HPR. We were interested in the coefficient of Post*Treat. The negative coefficient of Post*Treat indicates that HPR is effective in restraining the growth of newly-built house prices. Column 2 includes control variables in the analysis, which increased the R-squared value when compared with Column 1 . The coefficient of Post* Treat was still negative and statistically significant, confirming that HPR was effective, even after controlling for the other variables. Columns $3-4$ show the impacts in the relatively long-run. The coefficient of Post*Treat was -1.185 . This implies that the impacts of HPR exist in a relatively long-run, which is consistent with the conclusions in [21]. 
However, compared with Columns 1-2, the long-term effect of HPR on the newly-built house price index gradually diminished. In addition, in line with the existing literature, we found that land price, the annual gross domestic product, and per capita disposable income of urban residents were important factors that influenced house prices $[13,14,20,22,25,26]$.

Table 3. Home purchase restriction on house price index (Ordinary Least Squares).

\begin{tabular}{|c|c|c|c|c|c|c|c|c|}
\hline \multirow{3}{*}{ Variables } & \multicolumn{4}{|c|}{ Newly-Built House Price Index } & \multicolumn{4}{|c|}{ Second-Hand House Price Index } \\
\hline & \multicolumn{2}{|c|}{$\begin{array}{l}\text { Short-Term Effect } \\
\text { (2009: Q1 to 2012: Q4) }\end{array}$} & \multicolumn{2}{|c|}{$\begin{array}{l}\text { Long-Term Effect } \\
\text { (2009: Q1 to 2013: Q4) }\end{array}$} & \multicolumn{2}{|c|}{$\begin{array}{c}\text { Short-Term Effect } \\
\text { (2009: Q1 to 2012: Q4) }\end{array}$} & \multicolumn{2}{|c|}{$\begin{array}{l}\text { Long-Term Effect } \\
\text { (2009: Q1 to 2013: Q4) }\end{array}$} \\
\hline & (1) & (2) & (3) & (4) & (5) & (6) & (7) & (8) \\
\hline Post & $\begin{array}{l}-0.167 \\
(0.578)\end{array}$ & $\begin{array}{c}-2.777^{* * *} \\
(0.442)\end{array}$ & $\begin{array}{c}0.389 \\
(0.530)\end{array}$ & $\begin{array}{c}-4.421^{* * *} \\
(0.393)\end{array}$ & $\begin{array}{l}-0.231 \\
(0.472)\end{array}$ & $\begin{array}{c}-1.957^{* * *} \\
(0.394)\end{array}$ & $\begin{array}{l}-0.102 \\
(0.427)\end{array}$ & $\begin{array}{c}-3.174^{* * *} \\
(0.343)\end{array}$ \\
\hline Post*Treat & $\begin{array}{c}-1.873^{* *} \\
(0.769)\end{array}$ & $\begin{array}{c}-1.470^{* * *} \\
(0.421)\end{array}$ & $\begin{array}{c}-1.442^{* *} \\
(0.705)\end{array}$ & $\begin{array}{c}-1.185^{* * *} \\
(0.390)\end{array}$ & $\begin{array}{c}-2.704^{* * *} \\
(0.628)\end{array}$ & $\begin{array}{c}-0.994^{* * *} \\
(0.377)\end{array}$ & $\begin{array}{c}-2.156^{* * *} \\
(0.568)\end{array}$ & $\begin{array}{c}-0.697^{* *} \\
(0.342)\end{array}$ \\
\hline LnLP & & $\begin{array}{c}0.991 \\
(0.880)\end{array}$ & & $\begin{array}{l}1.538^{* *} \\
(0.615)\end{array}$ & & $\begin{array}{c}2.366^{* * *} \\
(0.787)\end{array}$ & & $\begin{array}{c}1.914^{* * *} \\
(0.540)\end{array}$ \\
\hline LagHP & & $\begin{array}{l}0.833^{* * *} \\
(0.0195)\end{array}$ & & $\begin{array}{l}0.893^{* * *} \\
(0.0165)\end{array}$ & & $\begin{array}{l}0.764^{* * *} \\
(0.0206)\end{array}$ & & $\begin{array}{l}0.829^{* * *} \\
(0.0176)\end{array}$ \\
\hline LnGDP & & $\begin{array}{l}7.587^{* * *} \\
(2.250)\end{array}$ & & $\begin{array}{l}3.738^{* *} \\
(1.582)\end{array}$ & & $\begin{array}{l}7.321^{* * * *} \\
(2.000)\end{array}$ & & $\begin{array}{l}3.617^{* * * *} \\
(1.383)\end{array}$ \\
\hline LnINC & & $\begin{array}{c}-8.739^{* * * *} \\
(3.064)\end{array}$ & & $\begin{array}{l}4.766^{* *} \\
(1.954)\end{array}$ & & $\begin{array}{c}-11.16^{* * *} \\
(2.723)\end{array}$ & & $\begin{array}{c}0.536 \\
(1.720)\end{array}$ \\
\hline Constant & $\begin{array}{c}4.359^{* * *} \\
(0.301)\end{array}$ & $\begin{array}{l}39.76^{* *} \\
(19.54)\end{array}$ & $\begin{array}{c}4.359^{* * *} \\
(0.292)\end{array}$ & $\begin{array}{c}-76.54^{* * *} \\
(12.31)\end{array}$ & $\begin{array}{c}3.460^{* * *} \\
(0.246)\end{array}$ & $\begin{array}{c}53.72^{* * *} \\
(17.30)\end{array}$ & $\begin{array}{c}3.460^{* * *} \\
(0.236)\end{array}$ & $\begin{array}{c}-37.78^{* * * *} \\
(10.81)\end{array}$ \\
\hline Observations & 1104 & 884 & 1380 & 1120 & 1104 & 884 & 1380 & 1120 \\
\hline R-squared & 0.015 & 0.751 & 0.004 & 0.750 & 0.047 & 0.717 & 0.027 & 0.715 \\
\hline Number of City & 69 & 59 & 69 & 59 & 69 & 59 & 69 & 59 \\
\hline
\end{tabular}

Notes: Standard errors in parentheses. ${ }^{* * *}$ represents significance at the $1 \%$ level, ${ }^{* *}$ represents significance at the $5 \%$ level, * represents significance at the $10 \%$ level. In Columns 1-4, the dependent variable is the newly-built house price index. In Columns $5-8$, the dependent variable is the second-hand house price index.

The results for the impacts of HPR on the second-hand housing market are shown in Columns 5-8 in Table 3. The short-term impacts of HPR are revealed in Columns 5-6, and the long-term effects are reported in Columns $7-8$. Columns 5-8 suggest that HPR leads to a drop in the growth of house prices in the second-hand housing market and that the impacts also exist in a relatively long-run. The results were robust after we introduced control variables. However, the impacts were relatively small in comparison to those in the newly-built housing market.

As the time for implementing localized HPR varied slightly in different cities (all of the cities in our sample introduced HPR between May 2010 and April 2011), we further restricted our sample to rule out the impacts of different time points. We restricted our data to the first quarter of 2009 to the first quarter of 2010, and the third quarter of 2011 to the fourth quarter of 2012, and applied a DID analysis to the selected periods. Table 4 reports the impacts of HPR on house prices for the subsample. As shown in Column 5, the impact of HPR on the newly-built housing market was negative and statistically significant at the level of $5 \%$. This implies that the impacts of HPR are robust.

In addition, the LagHP in our empirical analysis may lead to inconsistent estimators. Considering that our empirical model employed a dynamic panel data model with a large relatively large T, we also used a bias correction of the least-squares dummy variable (LSDV) to obtain a consistent estimator. As shown in Table 5, the results were consistent with the OLS model. Columns 1-4 report the impacts of HPR on the newly-built housing market. For the newly-built housing market, introducing HPR brought about a decline in the house price index, as suggested by the negative coefficients of PostTreat. The impacts of HPR on the second-hand housing market are revealed in Columns 5-8. Columns 5-6 show that HPR had negative impacts on the second-hand housing market in the short-run. However, Column 8 shows that the long-term effect of HPR on the second-hand house price growth was insignificant. 
Table 4. Home purchase restriction on house prices in selected periods (Ordinary Least Squares).

\begin{tabular}{cccccc}
\hline Variables & $\mathbf{( 1 )}$ & $\mathbf{( 2 )}$ & $\mathbf{( 3 )}$ & $\mathbf{( 4 )}$ & $\mathbf{( 5 )}$ \\
\hline Post & $-1.329^{* * *}$ & $-3.131^{* * *}$ & $-2.641^{* * *}$ & $-7.654^{* * *}$ & $-8.368^{* * *}$ \\
& $(0.499)$ & $(0.618)$ & $(0.462)$ & $(0.780)$ & $(0.866)$ \\
Post*Treat & $-1.840^{* * *}$ & $-1.254^{*}$ & $-1.225^{* *}$ & $-1.057^{* *}$ & $-1.030^{* *}$ \\
& $(0.664)$ & $(0.693)$ & $(0.512)$ & $(0.486)$ & $(0.485)$ \\
LnLP & & $6.491^{* * *}$ & $3.962^{* * *}$ & $2.672^{* * *}$ & $2.518^{* *}$ \\
& & $(1.377)$ & $(1.022)$ & $(0.983)$ & $(0.984)$ \\
LagHP & & $0.907^{* * *}$ & $0.889^{* * *}$ & $0.900^{* * *}$ \\
& & $(0.0407)$ & $(0.0386)$ & $(0.0389)$ \\
LnGDP & & & $12.33^{* * *}$ & $8.823^{* * *}$ \\
& & & $(1.587)$ & $(2.450)$ \\
LnINC & & & & $7.026^{*}$ \\
& & & & $(3.743)$ \\
Constant & $2.979^{* * *}$ & $-47.23^{* * *}$ & $-29.04^{* * *}$ & $-85.47^{* * *}$ & $-134.3^{* * * *}$ \\
& $(0.243)$ & $(10.65)$ & $(7.894)$ & $(10.43)$ & $(28.02)$ \\
Observations & 759 & 649 & 590 & 590 & 590 \\
R-squared & 0.080 & 0.113 & 0.578 & 0.621 & 0.624 \\
Number of City & 69 & 59 & 59 & 59 & 59 \\
\hline
\end{tabular}

Notes: Standard errors in parentheses. ${ }^{* * *}$ represents significance at the $1 \%$ level, ${ }^{* *}$ represents significance at the $5 \%$ level, * represents significance at the $10 \%$ level. The dependent variable is the newly-built house price index.

Similar to the study of $\mathrm{Wu}$ and $\mathrm{Li}$ [22], we employed a DID approach and found that for the treatment group, the house price declined significantly after the implementation of HPR. This implies that HPR effectively suppressed the rapid growth of house prices, which is in line with the conclusions in [19-22]. Moreover, unlike the existing literature, we studied the short-term effects and the long-term effects, respectively. The evidence shows that, compared to the short-term effects, the long-term effects were smaller. A plausible explanation is that some cities relax their HPR in the long-term.

Table 5. Home purchase restriction on house price index (biased-correction of least-squares dummy variable).

\begin{tabular}{|c|c|c|c|c|c|c|c|c|}
\hline \multirow{3}{*}{ Variables } & \multicolumn{4}{|c|}{ Newly-Built House Price Index } & \multicolumn{4}{|c|}{ Second-Hand House Price Index } \\
\hline & \multicolumn{2}{|c|}{$\begin{array}{l}\text { Short-Term Effect } \\
\text { (2009: Q1 to 2012: Q4) }\end{array}$} & \multicolumn{2}{|c|}{$\begin{array}{c}\text { Long-Term Effect } \\
\text { (2009: Q1 to 2013: Q4) }\end{array}$} & \multicolumn{2}{|c|}{$\begin{array}{c}\text { Short-Term Effect } \\
\text { (2009: Q1 to 2012: Q4) }\end{array}$} & \multicolumn{2}{|c|}{$\begin{array}{l}\text { Long-Term Effect } \\
\text { (2009: Q1 to 2013: Q4) }\end{array}$} \\
\hline & (1) & (2) & (3) & (4) & (5) & (6) & (7) & (8) \\
\hline \multirow[t]{2}{*}{ LagHP } & $0.887^{* * *}$ & $0.898^{* * *}$ & $0.888^{* * *}$ & $0.960^{* * *}$ & $0.853^{* * *}$ & $0.832^{* * *}$ & $0.851^{* * *}$ & $0.898^{* * *}$ \\
\hline & $(0.0238)$ & $(0.0256)$ & $(0.0213)$ & $(0.0205)$ & $(0.0294)$ & $(0.0288)$ & $(0.0250)$ & $(0.0230)$ \\
\hline \multirow[t]{2}{*}{ Post } & $-1.957^{* * *}$ & $-3.011^{* * *}$ & $-1.265^{* * *}$ & $-4.691^{* * *}$ & $-1.574^{* * *}$ & $-2.093^{* * *}$ & $-1.129^{* * *}$ & $-3.261^{* * *}$ \\
\hline & $(0.373)$ & $(0.367)$ & $(0.315)$ & $(0.415)$ & $(0.316)$ & $(0.327)$ & $(0.266)$ & $(0.360)$ \\
\hline \multirow[t]{2}{*}{ Post ${ }^{*}$ Treat } & $-1.853^{* * *}$ & $-1.322^{* * *}$ & $-1.492^{* * *}$ & $-1.018^{* *}$ & $-1.144^{* * *}$ & $-0.872^{*}$ & $-0.907^{* *}$ & -0.665 \\
\hline & $(0.481)$ & $(0.509)$ & $(0.437)$ & $(0.492)$ & $(0.414)$ & $(0.448)$ & $(0.370)$ & $(0.437)$ \\
\hline \multirow[t]{2}{*}{ LnLP } & & 0.536 & & 0.903 & & $2.054^{* * *}$ & & $1.443^{* *}$ \\
\hline & & $(0.889)$ & & $(0.675)$ & & $(0.777)$ & & $(0.562)$ \\
\hline \multirow[t]{2}{*}{ LnGDP } & & $5.514^{* *}$ & & $3.401^{* *}$ & & $5.360^{* *}$ & & $3.111^{* *}$ \\
\hline & & (2.499) & & $(1.712)$ & & $(2.183)$ & & $(1.474)$ \\
\hline \multirow[t]{2}{*}{ LnINC } & & -3.889 & & $6.504^{* * *}$ & & $-6.986^{* *}$ & & 2.275 \\
\hline & & $(3.666)$ & & $(2.177)$ & & $(3.162)$ & & (1.883) \\
\hline Observations & 1,035 & 884 & 1,311 & 1,120 & 1,035 & 884 & 1,311 & 1,120 \\
\hline Number of City & 69 & 59 & 69 & 59 & 69 & 59 & 69 & 59 \\
\hline
\end{tabular}

\subsection{Regional Heterogeneity Analysis of Home Purchase Restriction}

Our aforementioned analysis indicates that HPR leads to a drop in house price growth. However, the analysis may violate the common trend assumption and generate biased estimates due to the significant differences in house prices across cities. To address this concern, we apply a DIDID analysis in this part based on Equation (2). The results are shown in Tables 6 and 7. Columns (1-2) show the 
impacts of HPR on newly-built house prices in the eastern region. We are particularly interested in the coefficient of Post*Region*Treat, which shows that compare with the central cities and western cities, whether the net effects of HPR are more effective. In column (2), the coefficient is significantly negative, suggesting that the net impacts of HPR in eastern cities are less effective than the central and western cities. Columns (3-4) show the impact in the central cities, and the coefficient of Post*Region*Treat indicates whether HPR is more effective in the central cities than the eastern and western cities. The empirical results suggest that HPR in the central cities is more effective than in the eastern and western cities. The impacts of HPR on the western cities are reported in Columns (5-6). The evidence shows that HPR is effective in the western cities.

Table 7 reports the empirical results of HPR on the second-hand housing market. Columns 1-2 report the net effect of HPR in the eastern cities, Columns 3-4 reveal the net impacts of HPR in the central cities, and Columns 5-6 refers to the net effects in the western cities. The empirical results suggest that for the second-hand housing market, HPR is more effective in controlling the growth of house prices for the central cities. In contrast, the effect on cities in the eastern region was not larger than that in the central and western regions. However, there was no evidence to show that HPR is more effective in the western region. As a robust check, we also regressed the DIDID in the long-term (2009: Q1 to 2013: Q4) and the result was in line with the short-term analysis.

Table 6. Home Purchase Restriction on newly-built house prices cross regions.

\begin{tabular}{ccccccc}
\hline \multirow{2}{*}{ Variables } & \multicolumn{2}{c}{ Eastern Region } & \multicolumn{2}{c}{ Central Region } & \multicolumn{2}{c}{ Western Region } \\
\cline { 2 - 7 } & $\mathbf{( 1 )}$ & $\mathbf{( 2 )}$ & $\mathbf{( 3 )}$ & $\mathbf{( 4 )}$ & $\mathbf{( 5 )}$ & $\mathbf{( 6 )}$ \\
\hline Post & -0.146 & $-2.878^{* * *}$ & -0.342 & $-2.733^{* * *}$ & -0.0653 & $-2.647^{* * *}$ \\
& $(0.766)$ & $(0.541)$ & $(0.767)$ & $(0.530)$ & $(0.621)$ & $(0.452)$ \\
Post Treat & -0.392 & -0.131 & $-2.331^{* *}$ & $-1.918^{* * *}$ & $-2.184^{* * *}$ & $-1.866^{* * *}$ \\
& $(1.084)$ & $(0.582)$ & $(0.960)$ & $(0.538)$ & $(0.843)$ & $(0.454)$ \\
Post*Region & -0.0480 & 0.399 & 0.406 & -0.0464 & -0.760 & -1.145 \\
& $(1.164)$ & $(0.666)$ & $(1.165)$ & $(0.669)$ & $(1.702)$ & $(1.156)$ \\
Post* Region*Treat & $-2.613^{*}$ & $-2.574^{* * *}$ & 2.341 & $1.759^{*}$ & 1.783 & $2.473^{*}$ \\
& $(1.548)$ & $(0.836)$ & $(1.674)$ & $(0.898)$ & $(2.115)$ & $(1.313)$ \\
LnLP & & 1.289 & & 1.255 & & 1.028 \\
& & $(0.874)$ & & $(0.882)$ & & $(0.881)$ \\
LagHP & & $0.831^{* * *}$ & & $0.829^{* * *}$ & & $0.835^{* * *}$ \\
& & $(0.0193)$ & & $(0.0195)$ & & $(0.0195)$ \\
LnGDP & & & & & $6.836^{* * *}$ \\
& & $\left(2.670^{* * *}\right.$ & & $(2.250)$ & & $(2.276)$ \\
LnINC & & & $-9.240^{* * * *}$ & & $-7.845^{* *}$ \\
& & $-8.021^{* * *}$ & & $(3.075)$ & & $(3.091)$ \\
Constant & $4.359^{* * *}$ & $35.37^{*}$ & $4.359^{* * *}$ & $41.77^{* *}$ & $4.359^{* * *}$ & $34.75^{*}$ \\
& $(0.301)$ & $(19.47)$ & $(0.301)$ & $(19.57)$ & $(0.302)$ & $(19.63)$ \\
Observations & 1104 & 884 & 1104 & 884 & 1104 & 884 \\
R-squared & 0.022 & 0.756 & 0.021 & 0.753 & 0.016 & 0.752 \\
Number of City & 69 & 59 & 69 & 59 & 69 & 59 \\
\hline
\end{tabular}

Notes Standard errors in parentheses. ${ }^{* * *}$ represents significance at the $1 \%$ level, ${ }^{* *}$ represents significance at the $5 \%$ level, * represents significance at the $10 \%$ level. Dependent variable is the newly-built house price index. 
Table 7. Home purchase restriction on second-hand house prices across regions.

\begin{tabular}{|c|c|c|c|c|c|c|}
\hline \multirow{2}{*}{ Variables } & \multicolumn{2}{|c|}{ Eastern Region } & \multicolumn{2}{|c|}{ Central Region } & \multicolumn{2}{|c|}{ Western Region } \\
\hline & (1) & (2) & (3) & (4) & (5) & (6) \\
\hline Post & $\begin{array}{l}-0.271 \\
(0.625)\end{array}$ & $\begin{array}{c}-2.026^{* * *} \\
(0.483)\end{array}$ & $\begin{array}{l}-0.413 \\
(0.627)\end{array}$ & $\begin{array}{c}-1.906^{* * *} \\
(0.472)\end{array}$ & $\begin{array}{c}-0.0850 \\
(0.507)\end{array}$ & $\begin{array}{c}-1.875^{* * *} \\
(0.405)\end{array}$ \\
\hline Post*Treat & $\begin{array}{l}-1.204 \\
(0.884)\end{array}$ & $\begin{array}{c}-0.0106 \\
(0.520)\end{array}$ & $\begin{array}{c}-2.968^{* * *} \\
(0.785)\end{array}$ & $\begin{array}{c}-1.467^{* * *} \\
(0.480)\end{array}$ & $\begin{array}{c}-3.218^{* * *} \\
(0.688)\end{array}$ & $\begin{array}{c}-1.166^{* * *} \\
(0.409)\end{array}$ \\
\hline Post*Region & $\begin{array}{l}0.0933 \\
(0.950)\end{array}$ & $\begin{array}{c}0.306 \\
(0.595)\end{array}$ & $\begin{array}{c}0.421 \\
(0.953)\end{array}$ & $\begin{array}{c}-0.0739 \\
(0.595)\end{array}$ & $\begin{array}{l}-1.093 \\
(1.389)\end{array}$ & $\begin{array}{l}-0.760 \\
(1.033)\end{array}$ \\
\hline Post*Region*Treat & $\begin{array}{c}-2.681^{* *} \\
(1.263)\end{array}$ & $\begin{array}{c}-1.909^{* *} \\
(0.747)\end{array}$ & $\begin{array}{c}1.514 \\
(1.369)\end{array}$ & $\begin{array}{l}1.806^{* *} \\
(0.798)\end{array}$ & $\begin{array}{l}2.888^{*} \\
(1.726)\end{array}$ & $\begin{array}{c}1.212 \\
(1.173)\end{array}$ \\
\hline LnLP & & $\begin{array}{c}2.600^{* * *} \\
(0.785)\end{array}$ & & $\begin{array}{c}2.632^{* * *} \\
(0.787)\end{array}$ & & $\begin{array}{c}2.409^{* * *} \\
(0.790)\end{array}$ \\
\hline LagHP & & $\begin{array}{l}0.760^{* * *} \\
(0.0205)\end{array}$ & & $\begin{array}{l}0.761^{* * *} \\
(0.0206)\end{array}$ & & $\begin{array}{l}0.764^{* * *} \\
(0.0207)\end{array}$ \\
\hline LnGDP & & $\begin{array}{c}6.688^{* * *} \\
(2.016)\end{array}$ & & $\begin{array}{c}7.477^{* * *} \\
(2.004)\end{array}$ & & $\begin{array}{c}7.103^{* * *} \\
(2.025)\end{array}$ \\
\hline LnINC & & $\begin{array}{c}-10.73^{* * *} \\
(2.732)\end{array}$ & & $\begin{array}{c}-11.62^{* * *} \\
(2.727)\end{array}$ & & $\begin{array}{c}-10.93^{* * *} \\
(2.748)\end{array}$ \\
\hline Constant & $\begin{array}{c}3.460^{* * *} \\
(0.245)\end{array}$ & $\begin{array}{c}51.13^{* * *} \\
(17.30)\end{array}$ & $\begin{array}{c}3.460^{* * *} \\
(0.246)\end{array}$ & $\begin{array}{c}55.35^{* * *} \\
(17.29)\end{array}$ & $\begin{array}{c}3.460^{* * *} \\
(0.246)\end{array}$ & $\begin{array}{c}52.38^{* * *} \\
(17.39)\end{array}$ \\
\hline Observations & 1104 & 884 & 1104 & 884 & 1104 & 884 \\
\hline R-squared & 0.055 & 0.721 & 0.050 & 0.720 & 0.050 & 0.717 \\
\hline Number of City & 69 & 59 & 69 & 59 & 69 & 59 \\
\hline
\end{tabular}

Notes Standard errors in parentheses. ${ }^{* * *}$ represents significance at the $1 \%$ level, ${ }^{* *}$ represents significance at the $5 \%$ level, * represents significance at the $10 \%$ level. Dependent variable is the second-hand house price index.

The empirical results from this section suggest that there is regional heterogeneity in the impacts of HPR. This echoes the viewpoints of Wu and Li [22], who argued that the impacts of HPR differed across cities. The heterogeneity in the impacts of HPR can be partly explained by the supply-demand in different regions. In the eastern region, the land supply has declined since 2003 [29]. This has led to a drop in housing supply. On the demand side, however, the main problem facing the eastern cities is the rapid increase in housing demand, because the eastern cities have been the main source of population inflows [25]. As a result, the housing supply can hardly meet the demand in the eastern cities. In fact, although HPR may suppress some speculative housing demands in the eastern cities, the overall housing demand is still sufficiently strong, which makes the HPR less effective on the house price growth. In contrast, for the central and western cities, the main problem facing them is the oversupply in the housing market [30]. On one hand, the proportion of land supply in the central and western regions has been growing continuously. On the other hand, the central and western cities have less housing demand than the eastern cities. A combination of the supply-side and demand-side fundamentals makes these cities more sensitive to HPR.

Furthermore, the heterogeneity in the impacts of HPR can also be explained by the different expectations in the housing market across regions. For the eastern region, both home buyers and real estate developers are optimistic about the housing market, because they believe that house prices will continue increasing [31-33]. As a result, real estate developers prefer to delay property sales and wait for the housing market boom, thereby reducing the effect of HPR in the eastern cities. By calculating the share of unsold inventory in sales volume, Wu et al. [30] found that during 2010 and 2011, the unsold inventories held by developers increased dramatically in 12 major cities in China. However, for the central and western cities, real estate developers may be more concerned about their high inventories and be more eager to promote sales, thereby decreasing house prices. Overall, all of the explanations suggest that compared with the eastern cities, the central and western cities are more sensitive to house prices [32], thereby decreasing the impacts of HPR. 


\subsection{Impacts of Home Purchase Restriction Removal on House Prices}

Although our analysis suggests that HPR is effective in restraining rapid growth in house prices, most cities have relaxed and even removed it since 2014. On one hand, local governments regard land sales as a major part of local fiscal income [19]. As HPR curbs the growth in house prices, the land sales of local government have also been negatively affected. On the other hand, for some western and central cities, the main problem facing them is the oversupply in the housing market [30]. However, the implementation of HPR aggravated the problem of high inventory. Furthermore, HPR negatively affected the development of the real estate industry and economy. Therefore, the local governments had less incentive to continue HPR and decided to remove it. As shown in Table 8, the majority of cities in our sample have abandoned HPR since 2014. Notably, except for Beijing, Shanghai, Guangzhou, and Shenzhen (all first-tier cities), all other cities in our sample abandoned HPR in 2014.

Table 8. Home purchase restriction removal.

\begin{tabular}{cccccc}
\hline CITY & TIME & CITY & TIME & CITY & TIME \\
\hline Hohhot & 2014.06 & Hefei & 2014.08 & Xian & 2014.09 \\
Jinan & 2014.07 & Taiyuan & 2014.08 & Dalian & 2014.09 \\
Chengdu & 2014.07 & Changsha & 2014.08 & Lanzhou & 2014.09 \\
Haikou & 2014.07 & Zhengzhou & 2014.08 & Xining & 2014.09 \\
Changchun & 2014.07 & Kunming & 2014.08 & Shenyang & 2014.09 \\
Wenzhou & 2014.07 & Xiamen & 2014.08 & Nanjing & 2014.09 \\
Ningbo & 2014.07 & Nanchang & 2014.08 & Fuzhou & 2014.09 \\
Shijiazhuang & 2014.07 & Harbin & 2014.08 & Wuhan & 2014.09 \\
Haikou & 2014.07 & Yinchuan & 2014.08 & Nanning & 2014.10 \\
Xuzhou & 2014.08 & Hangzhou & 2014.08 & Sanya & 2014.10 \\
Qingdao & 2014.08 & Wuxi & 2014.08 & Tianjin & 2014.10 \\
Jinhua & 2014.08 & Guiyang & 2014.09 & Urumqi & 2014.10 \\
\hline \multicolumn{7}{c}{ Source: Author. }
\end{tabular}

In this section, we estimate the impacts of HPR removal on the housing market. We used data from 2012: Q1 to 2016: Q2 to investigate the impacts of HPR removal based on Equation (1). Tables 9 and 10 display the effects of HPR removal on the housing market. Table 9 reports the impacts of HPR removal on the housing market based on the OLS method. Columns 1-2 show the impacts of HPR removal on the newly-built housing market. In Column 1, the coefficient of Post*Treat was positive and statistically significant at the level of $10 \%$. However, after introducing all of the other variables in the model, the coefficient of Post*Treat was insignificant, as shown in Column 2. Meanwhile, the R-squared value increased significantly when compared with Column 1, which can be explained by the fact that we introduced many relevant control variables. In particular, LagHP may be a major contributor to the increase in the R-squared value as existing evidence proves that changes in house prices are serially correlated over time [34]. To address the concern that the effects may be influenced by the serial correlation of house prices, we investigated the impacts of HPR on the housing market by using the biased-correction LSDV, the results of which are reported in Table 10. After adjusting the impacts of serial correlation, we found that HPR was still not significant on the newly-built housing market. Moreover, there was no evidence to show that the removal of HPR affected the growth of house prices for the second-hand housing market. There are two likely explanations for the results. First, HPR has a poor execution in some cities, especially in the long-run. This is consistent with our above findings, which showed that the effects of HPR gradually diminished in the relatively long-run. Second, for those cities with a higher inventory, as the supply and demand have not dramatically changed in these cities, the removal of HPR will not push up house prices. 
Table 9. Removal of home purchase restriction on house prices (Ordinary Least Squares).

\begin{tabular}{ccccc}
\hline \multirow{2}{*}{ Variables } & \multicolumn{2}{c}{ Newly-Built House Price Index } & \multicolumn{2}{c}{ Second-Hand House Price Index } \\
\cline { 2 - 5 } & $\mathbf{( 1 )}$ & $\mathbf{( 2 )}$ & $\mathbf{( 1 )}$ & $\mathbf{( 2 )}$ \\
\hline Post & $-5.726^{* * *}$ & -0.785 & $-2.896^{* * *}$ & -0.0748 \\
& $(0.438)$ & $(0.480)$ & $(0.381)$ & $(0.379)$ \\
Post*Treat & $1.131^{*}$ & 0.252 & 0.672 & -0.0897 \\
& $(0.615)$ & $(0.413)$ & $(0.535)$ & $(0.345)$ \\
LnLP & & 0.743 & & 0.693 \\
& & $(0.667)$ & & $(0.556)$ \\
LagHP & & $0.885^{* * *}$ & $0.933^{* * *}$ \\
& & $(0.0245)$ & & $(0.0238)$ \\
LnGDP & 1.417 & 0.164 \\
& & $(1.818)$ & & $(1.499)$ \\
LnINC & 0.502 & 1.423 \\
& & $(2.019)$ & $1.599^{* * * *}$ & $(1.696)$ \\
Constant & $3.484^{* * *}$ & -18.88 & $(0.172)$ & -20.77 \\
& $(0.197)$ & $(16.92)$ & 1173 & $(14.26)$ \\
Observations & 1173 & 942 & 0.078 & 942 \\
R-squared & 0.205 & 0.742 & 69 & 0.725 \\
Number of City & 69 & 59 & 59 \\
\hline
\end{tabular}

Notes: Standard errors in parentheses. ${ }^{* * *}$ represents significance at the $1 \%$ level, ${ }^{* *}$ represents significance at the $5 \%$ level, * represents significance at the $10 \%$ level.

Table 10. Removal of home purchase restriction on house prices (biased-correction of least-squares dummy variable).

\begin{tabular}{ccccc}
\hline \multirow{2}{*}{ Variables } & \multicolumn{2}{c}{ Newly-Built House Price Index } & \multicolumn{2}{c}{ Second-Hand House Price Index } \\
\cline { 2 - 5 } & $\mathbf{( 1 )}$ & $\mathbf{( 2 )}$ & $\mathbf{( 1 )}$ & $\mathbf{( 2 )}$ \\
\hline LagHP & $1.018^{* * *}$ & $1.011^{* * *}$ & $1.053^{* * *}$ & $1.051^{* * *}$ \\
& $(0.0160)$ & $(0.0209)$ & $(0.0118)$ & $(0.0152)$ \\
Post & $-0.437^{*}$ & $-0.722^{* *}$ & 0.00675 & -0.109 \\
& $(0.257)$ & $(0.360)$ & $(0.193)$ & $(0.307)$ \\
Post*Treat & 0.0189 & 0.0718 & -0.229 & -0.253 \\
& $(0.407)$ & $(0.416)$ & $(0.322)$ & $(0.329)$ \\
LnLP & & 0.279 & & 0.292 \\
& & $(0.755)$ & & $(0.581)$ \\
LnGDP & 0.721 & & -0.462 \\
& & $(1.978)$ & & $(1.563)$ \\
LnINC & 0.166 & & 0.702 \\
& & $(1.760)$ & $11.379)$ \\
Observations & 1104 & 942 & 69 & 942 \\
Number of City & 69 & 59 & 59 \\
\hline
\end{tabular}

Notes: Standard errors in parentheses. ${ }^{* * *}$ represents significance at the $1 \%$ level, ${ }^{* *}$ represents significance at the $5 \%$ level, * represents significance at the $10 \%$ level.

\section{Robustness Test}

In our above analysis, the DID approach may generate a biased estimate. First, HPR is not a natural experiment in our research. Instead, it has a potential selection bias problem because the HPR was only introduced by major cities with a more active housing market. Meanwhile, there were some unobservable characteristics for the treatment group and the control group. In order to solve the problem of DID in our research, we applied the propensity score matching method and DID specification as our robustness test.

Table 11 reports the estimation results of the logit regression. The dependent variable was whether the city belonged to the treatment group and the independent variables were all of the control variables including LogLP, LagHP, LogPGDP (per capita GDP), and LogINC (disposable income). Table 12 shows 
the average effect of treatment on the treated group (ATTs) based on the radius matching method. We tested whether there was a systematic difference between the control group and the treatment group after matching. After matching, all of the variables were statistically insignificant, indicating that there was no systematic difference between those variables after matching.

Table 11. Estimation results of the logit regression.

\begin{tabular}{cc}
\hline Variables & Logit Coeff \\
\hline LnLP & $1.895^{* * *}$ \\
& $(0.194)$ \\
LagHP & $0.067^{* * *}$ \\
& $(0.022)$ \\
LnPGDP & $3.224^{* * *}$ \\
& $(0.361)$ \\
LnINC & $-5.400^{* * *}$ \\
& $(0.654)$ \\
Constant & -2.002 \\
& $(3.037)$ \\
Observations & 830 \\
\hline
\end{tabular}

Notes: Standard errors in parentheses. ${ }^{* * *}$ represents significance at the $1 \%$ level, ${ }^{* *}$ represents significance at the $5 \%$ level, * represents significance at the $10 \%$ level.

Table 12. Comparisons of average effect of treatment on the treated group (by radius matching).

\begin{tabular}{cccccc}
\hline Variable & Sample & Treat Group & Control Group & ATT & t-Value \\
\hline \multirow{2}{*}{ LnLP } & Pre-matching & 8.1489 & 7.1847 & 0.964 & $4.67^{* * *}$ \\
& Post-matching & 7.506 & 7.5933 & -0.087 & -0.27 \\
LagHP & Pre-matching & 1.3225 & 1.3095 & 0.013 & 0.02 \\
& Post-matching & 0.91111 & 1.825 & -0.914 & -0.56 \\
LnPGDP & Pre-matching & 10.697 & 10.252 & 0.445 & $4.06^{* * *}$ \\
& Post-matching & 10.4 & 10.356 & 0.044 & 0.18 \\
LnINC & Pre-matching & 8.481 & 8.2875 & 0.194 & $3.20^{* * *}$ \\
& Post-matching & 8.3486 & 8.3743 & -0.026 & -0.22 \\
\hline
\end{tabular}

Notes: Pre-matching refers to the treatment group without matching with the control group; Post-matching refers to the group after matching.

Figure 2 displays the kernel density plots of the treatment group and the control group before and after matching. As shown in Figure 2a, there was a systematical difference between the density function of the treatment group and the control group before matching. This means that simply comparing the difference between the treatment group and the control group will lead to biased results. After matching, as shown in Figure 2b, the two curves were more similar to each other, which means that the covariate characteristics between the treatment group and the control group were closer to the treatment group. Table 13 reports the PSM-DID estimate of HPR. The estimate of the impacts of HPR on house prices was -1.2 and was significant at the level of $5 \%$. The results of PSM-DID indicate that after introducing the PSM, the impacts of HPR on house price growth are still significant. This implies that the implementation of HPR has negative impacts on the growth of house prices. 


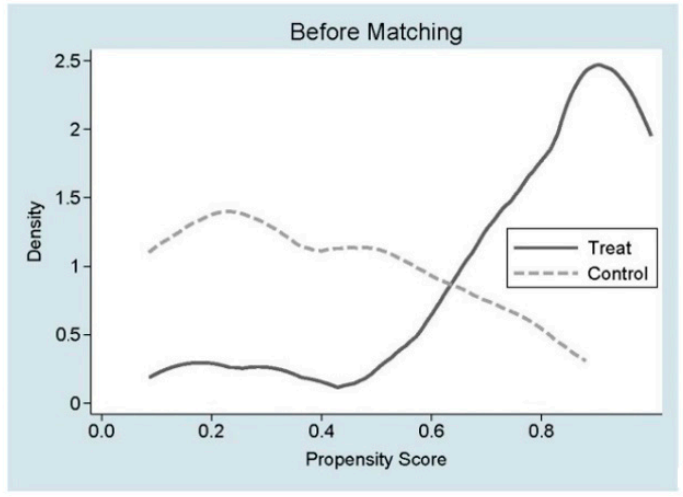

(a)

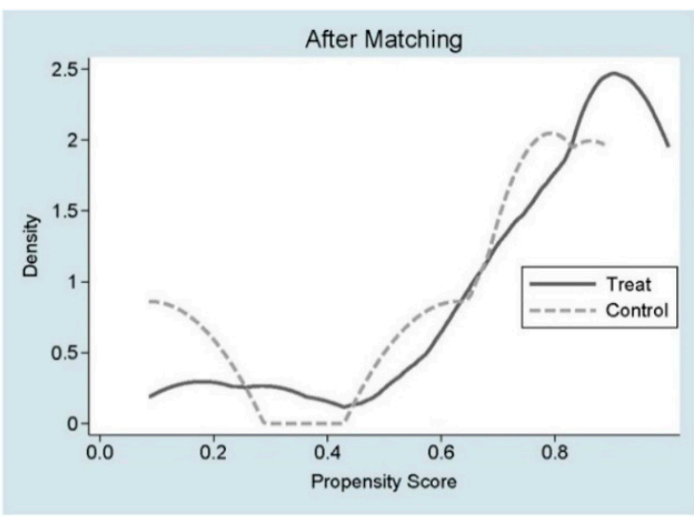

(b)

Figure 2. Kernel density distributions of the propensity scores between the treatment group and the control group. (a) Plot of the propensity score nuclear density before matching. (b) Plot of the propensity score nuclear density after matching.

Table 13. Impacts of HPR on the newly-built house price index.

\begin{tabular}{ccccc}
\hline Variable & HP & S.E. & $|\mathbf{t}|$ & P>|t| \\
\hline Diff (T-C) Before & 0.790 & 0.328 & 2.41 & $0.016^{* *}$ \\
Diff (T-C) After & -0.410 & 0.452 & 0.91 & 0.364 \\
Diff-in-Diff & -1.200 & 0.558 & 2.15 & $0.032^{* *}$ \\
\hline
\end{tabular}

Notes: Standard errors in parentheses. ${ }^{* * *}$ represents significance at the $1 \%$ level, ${ }^{* *}$ represents significance at the $5 \%$ level, ${ }^{*}$ represents significance at the $10 \%$ level.

\section{Conclusions}

In recent years, due to the rising demand for housing and the relative inelastic housing supply, house prices have been pushed up dramatically in China. This arouses wide concerns among Chinese households, economists, and the government. The surging house prices not only damage the development of the housing market, but also that of the economy. To curb the rapid growth of house prices and prompt the functioning of the housing market, major cities introduced the home purchase restriction in 2010-2011 and recently in 2016. By imposing purchase requirements and tightening credit, HPR has direct impacts on housing demand, and further affects house prices.

This paper studied the impacts of HPR on the housing market. By employing a DID approach, we studied the short-term and long-term effects of the implementation of HPR on the growth of house prices. We found that HPR effectively reduced the growth of house prices for the newly-built housing market and the second-hand housing market in the short-run. Additionally, the negative impacts of HPR on house prices were robust. In a relatively long period, the effects still existed, but the magnitude gradually diminished. Our analysis also suggests that the impacts of HPR vary across regions. The impacts of HPR in the eastern region were less effective than that in the central and western cities. In contrast, the impacts of HPR were more pronounced in the central and western cities. This can be explained by the heterogeneous fundamentals and expectations in different regions. Finally, unlike previous studies, we also tracked the effects of HPR dynamics on the housing market. In particular, most cities (except for Beijing, Shanghai, Guangzhou, and Shenzhen) have removed HPR since. Based on the data before and after 2014, we further evaluated the impacts of HPR removal on the housing market. (In fact, since 2017, 29 cities in our treatment group that had removed HPR in 2014 returned to HPR in 2017, except for Hohhot, Xining, Yinchuan, Urumqi, Wenzhou, and Jinhua.) However, we found no evidence that HPR removal will affect house prices. 
This paper has important policy implications for the housing market in China. First, we found that HPR was effective in controlling the surging house prices in the short-run, but it does not perform well in the long-run. This implies that HPR is more effective as a short-run regulation rather than a long-term regulation. Therefore, to improve the long-term development of the real estate industry, it is imperative to establish a long-term regulation mechanism. This is consistent with the report on the work of the government of the Second Session of the $13^{\text {th }}$ National People's Congress of the People's Republic of China, which mentioned that the government aimed at reforming and improving mechanisms for conducting regulation over the real estate market. (Report on the work of the government of the Second Session of the $13^{\text {th }}$ National People's Congress of the People's Republic of China, 2019, http://language.chinadaily.com.cn/a/201903/18/WS5c8efa3da3106c65c34ef20c.html.)

Second, the Chinese housing market varies across different regions. As a result, the effect of regulation policies also varies. In our analysis, the impacts of HPR were more effective in central and western cities than in eastern cities, which indicates that the one-size-fits-all HPR policy is not suitable for the Chinese housing market. Therefore, it is important to implement differential regional regulation, which is similar to the conclusions in [22,23].

Third, there is no evidence to show that policy uncertainty in HPR affects house prices as expected. This implies that improving the sustainability of policies is important for the Chinese housing market. Moreover, this is also relevant to other developing economies with a surging housing market. For these countries, our paper suggests that the sustainability of housing market policies is important for improving the functioning of the housing market.

Author Contributions: All authors contributed equally to this work and all authors read and approved the final manuscript.

Funding: This paper was supported by the National Natural Science Foundation of China (NSFC) under grant Nos. 71573244, 71532013, and 71403260.

Acknowledgments: The authors would like to thank the anonymous referees as well as the editors.

Conflicts of Interest: The authors declare no conflicts of interest.

\section{Appendix A}

Table A1. City list of the treatment and control groups.

\begin{tabular}{|c|c|}
\hline Treatment Group & Control Group \\
\hline \multicolumn{2}{|c|}{ A. Implementation of HPR (2009: Q1 to 2013: Q4) } \\
\hline $\begin{array}{l}\text { Beijing, Tianjin, Shijiazhuang, Taiyuan, Hohhot, } \\
\text { Shenyang, Dalian, Changchun, Harbin, Shanghai, } \\
\text { Nanjing, Hangzhou, Ningbo, Hefei, Fuzhou, Xiamen, } \\
\text { Nanchang, Jinan, Qingdao, Zhengzhou, Wuhan, } \\
\text { Changsha, Guangzhou, Shenzhen, Nanning, Haikou, } \\
\text { Chengdu, Guiyang, Kunming, Xian, Lanzhou, Xining, } \\
\text { Yinchuan, Urumqi, Wuxi, Xuzhou, Wenzhou, Jinhua, } \\
\text { and Sanya. }\end{array}$ & $\begin{array}{l}\text { Chongqing, Tangshan, Qinhuangdao, Baotou, } \\
\text { Dandong, Jinzhou, Jilin, Mudanjiang, Yangzhou, } \\
\text { Bengbu, Anqing, Quanzhou, Jiujiang, Ganzhou, } \\
\text { Yantai, Jining, Luoyang, Pingdingshan, Yichang, } \\
\text { Xiangyang, Yueyang, Changde, Huizhou, Zhanjiang, } \\
\text { Shaoguan, Guilin, Beihai, Luzhou, Nanchong, and } \\
\text { Zunyi. }\end{array}$ \\
\hline \multicolumn{2}{|c|}{ B. Removal of HPR (2012: Q1 to 2016: Q2) } \\
\hline $\begin{array}{l}\text { Tianjin, Shijiazhuang, Taiyuan, Hohhot, Shenyang, } \\
\text { Dalian, Changchun, Harbin, Nanjing, Hangzhou, } \\
\text { Ningbo, Hefei, Fuzhou, Xiamen, Nanchang, Jinan, } \\
\text { Qingdao, Zhengzhou, Wuhan, Changsha, Nanning, } \\
\text { Haikou, Chengdu, Guiyang, Kunming, Xian, } \\
\text { Lanzhou, Xining, Yinchuan, Urumqi, Wuxi, Xuzhou, } \\
\text { Wenzhou, Jinhua, and Sanya. }\end{array}$ & $\begin{array}{l}\text { Beijing, Shanghai, Guangzhou, Shenzhen, Chongqing, } \\
\text { Tangshan, Qinhuangdao, Baotou, Dandong, Jinzhou, } \\
\text { Jilin, Mudanjiang, Yangzhou, Bengbu, Anqing, } \\
\text { Quanzhou, Jiujiang, Ganzhou, Yantai, Jining, } \\
\text { Luoyang, Pingdingshan, Yichang, Xiangyang, } \\
\text { Yueyang, Changde, Huizhou, Zhanjiang, Shaoguan, } \\
\text { Guilin, Beihai, Luzhou, Nanchong, and Zunyi. }\end{array}$ \\
\hline
\end{tabular}




\section{References}

1. Zou, G.; Chau, K. Determinants and Sustainability of House Prices: The Case of Shanghai, China. Sustainability 2015, 7, 4524-4548. [CrossRef]

2. Peek, J.; Wilcox, J.A. Housing, Credit Constraints, and Macro Stability: The Secondary Mortgage Market and Reduced Cyclicality of Residential Investment. Am. Econ. Rev. 2006, 96, 135-140. [CrossRef]

3. Jeske, K.; Krueger, D.; Mitman, K. Housing, Mortgage Bailout Guarantees and the Macro Economy. J. Monet. Econ. 2013, 60, 917-935. [CrossRef]

4. Li, L.; Wu, X. Housing Price and Entrepreneurship in China. J. Comp. Econ. 2014, 42, 436-449. [CrossRef]

5. Li, S.; Whalley, J.; Zhao, X. Housing Price and Household Savings Rates: Evidence from China. J. Chin. Econ. Bus. Stud. 2013, 11, 197-217. [CrossRef]

6. Wang, X.; Wen, Y. Housing Prices and the High Chinese Saving Rate Puzzle. China Econ. Rev. 2012, 23, 265-283. [CrossRef]

7. Wan, J. Household Savings and Housing Prices in China. World Econ. 2015, 38, 172-192. [CrossRef]

8. Cohen, M. A systematic review of urban sustainability assessment literature. Sustainability 2017, 9, 2048. [CrossRef]

9. Wei, S.J.; Allen, R. Beyond the Crisis: Growth Prospects and Critical Challenges for Major Economies over the Next Ten Years; The Chazen Institute Report on World Business \& the Economy; Columbia University: Broadway, New York, NY, USA, 2010.

10. Cao, J.A.; Keivani, R. The Limits and Potentials of the Housing Market Enabling Paradigm: An Evaluation of China's Housing Policies from 1998 to 2011. Hous. Stud. 2014, 29, 44-68. [CrossRef]

11. Wei, Y.; Huang, C.; Lam, P.; Sha, Y.; Feng, Y. Using urban-carrying capacity as a benchmark for sustainable urban development: An empirical study of Beijing. Sustainability 2015, 7, 3244-3268. [CrossRef]

12. Yin, S.; Ma, Z.; Song, W.; Liu, C. Spatial Justice of a Chinese Metropolis: A Perspective on Housing Price-to-Income Ratios in Nanjing, China. Sustainability 2019, 11, 1808. [CrossRef]

13. Xiao, L.; Qiu, Q.; Gao, L. Chinese Housing Reform and Social Sustainability: Evidence from Post-reform Home Ownership. Sustainability 2016, 8, 1053. [CrossRef]

14. Zhang, X.; Liu, X.; Hang, J.; Yao, D.; Shi, G. Do urban rail transit facilities affect housing prices? Evidence from China. Sustainability 2016, 8, 380. [CrossRef]

15. Li, J.; Xu, Y. Evaluating Restrictive Measures Containing Housing Prices in China: A Data Envelopment Analysis Approach. Urban Stud. 2016, 53, 2654-2669. [CrossRef]

16. Du, Z.; Zhang, L. Home-Purchase Restriction, Property Tax and Housing Price in China: A Counterfactual Analysis. J. Econom. 2015, 188, 558-568. [CrossRef]

17. Wang, M.; Huang, Y. The Influence of the Purchase and Property Tax on the House Price: Analysis Based on Long Term Dynamic Equilibrium. J. World Econ. 2013, 1, 141-159. (In Chinese)

18. Zhou, Z. Housing Market Sentiment and Intervention Effectiveness: Evidence from China. Emerg. Mark. Rev. 2018, 35, 91-110. [CrossRef]

19. Sun, W.; Zheng, S.; Geltner, D.M.; Wang, R. The Housing Market Effects of Local Home Purchase Restrictions: Evidence from Beijing. J. Real Estate Financ. Econ. 2017, 55, 288-312. [CrossRef]

20. Yan, Y.; Ouyang, H. Effects of House-sale Restrictions in China: A Difference-in-Difference Approach. Appl. Econ. Lett. 2018, 25, 1051-1057. [CrossRef]

21. Li, V.J.; Cheng, A.W.W.; Cheong, T.S. Home Purchase Restriction and Housing Price: A Distribution Dynamics Analysis. Reg. Sci. Urban. Econ. 2017, 67,1-10. [CrossRef]

22. Wu, Y.; Li, Y. Impact of Government Intervention in the Housing Market: Evidence from the Housing Purchase Restriction Policy in China. Appl. Econ. 2018, 50, 691-705. [CrossRef]

23. Jia, S.; Wang, Y.; Fan, G.Z. Home-Purchase Limits and Housing Prices: Evidence from China. J. Real Estate Financ. Econ. 2018, 56, 386-409. [CrossRef]

24. El-Montasser, G.; Ajmi, A.N.; Chang, T.; Simo-Kengne, B.D.; André, C.; Gupta, R. Cross-country evidence on the causal relationship between policy uncertainty and housing prices. J. Hous. Res. 2016, 25, 195-211.

25. Mou, Y.; He, Q.; Zhou, B. Detecting the Spatially Non-stationary Relationships between Housing Price and Its Determinants in China: Guide for Housing Market Sustainability. Sustainability 2017, 9, 1826. [CrossRef]

26. Lin, S.H.; Li, J.H.; Hsieh, J.C.; Huang, X.; Chen, J.T. Impact of Property Tax on Housing-Market Disequilibrium in Different Regions: Evidence from Taiwan for the period 1982-2016. Sustainability 2018, 10, 4318. [CrossRef] 
27. Duflo, E. Schooling and Labor Market Consequences of School Construction in Indonesia: Evidence from an Unusual Policy Experiment. Am. Econ. Rev. 2001, 91, 795-813. [CrossRef]

28. Heckman, J.J.; Ichimura, H.; Todd, P.E. Matching as an Econometric Evaluation Estimator: Evidence from Evaluating a Job Training Programme. Rev. Econ. Stud. 1997, 64, 605. [CrossRef]

29. Liang, W.; Lu, M.; Zhang, H. Housing Prices Raise Wages: Estimating the Unexpected Effects of Land Supply Regulation in China. J. Hous. Econ. 2016, 33, 70-81. [CrossRef]

30. Wu, J.; Gyourko, J.; Deng, Y. Evaluating the Risk of Chinese Housing Markets: What We Know and What We Need to Know. China Econ. Rev. 2016, 39, 91-114. [CrossRef]

31. Wang, Z.; Zhang, Q. Fundamental factors in the housing markets of China. J. Hous. Econ. 2014, $25,53-61$. [CrossRef]

32. Liu, T.Y.; Chang, H.L.; Su, C.W.; Jiang, X.Z. China's housing bubble burst? Econ. Transit. 2016, 24, 361-389. [CrossRef]

33. Fang, H.; Gu, Q.; Xiong, W.; Zhou, L.A. Demystifying the Chinese housing boom. NBER Macroecon. Annu. 2016, 30, 105-166. [CrossRef]

34. Glaeser, E.L.; Gyourko, J.; Morales, E.; Nathanson, C.G. Housing dynamics: An urban approach. J. Urban Econ. 2014, 81, 45-56. [CrossRef]

(C) 2019 by the authors. Licensee MDPI, Basel, Switzerland. This article is an open access article distributed under the terms and conditions of the Creative Commons Attribution (CC BY) license (http://creativecommons.org/licenses/by/4.0/). 